\title{
Analysis and Design of Flat Slab
}

\author{
Gaurav Ravindra Chavan \\ PG Student, Department of Applied Mechanics \\ Walchand College of Engineering, Sangli, Maharashtra, India \\ Dr. S. N. Tande \\ Professor, Department of Applied Mechanics, \\ Walchand College of Engineering, Sangli, Maharashtra, India
}

\begin{abstract}
A floor system plays an important role in overall cost and service of the building. Nowadays flat slabs are used in most of the building because of its advantages. There are two methods of analysis of RC flat slab viz. Direct Design Method and Equivalent Frame Method. The objective of this paper is to present analysis and design of RC flat slab using two different methods and compare the superiority of the two methods over one another by various aspects. Also Finite element analysis \& Equivalent frame analysis is carried out by using software SAFE.
\end{abstract}

Keywords- RC Flat Slab, Direct Design Method (DDM), Equivalent Frame Method (EFM), SAFE

\section{INTRODUCTION}

A slab is a flat two dimensional planar structural element having thickness is small as compared to its other two dimensions. It provides a working flat surface or a covering shelter in buildings. It primarily transfers the load by bending in one or two directions. Reinforced concrete slabs are used in floors, roofs and walls of buildings and as the decks of bridges. The floor system of a structure can take many forms such as in situ solid slab, ribbed slab or pre-cast units. Slabs may be supported on monolithic concrete beam, steel beams, walls or directly over the columns. Concrete slab behave primarily as flexural members and the design is similar to that of beams. [1]

Flat plate/slabs are economical since they have no beams and hence can reduce the floor height by 10 $15 \%$. Hence flat plate /slab construction has been in practice in west for a long time. However the technology has seen large scale use only in last decade and is one of the rapidly developing technologies in Indian building industry today. [2] Material advances in concrete quality available for construction, improvement in quality of construction; easier design and numerical techniques has contributed to the rapid growth technology in India.

\section{METHODOLOGY}

For this IS 456-2000 permits use of any one of the following two methods:

(a) The Direct Design Method

(b) The Equivalent Frame Method

Both Direct Design Method and Equivalent Frame methods are approximate methods so values of bending moment and shear force differ significantly. So with the advent of sophisticated finite element analysis programs which are relatively easy to use and have significant economy can be used as an alternative for above two methods.

\subsection{Direct Design Method:}

DDM is very simplest and approximate method for analysis of flat slab. In this method total moment (M0) is calculated and then it distributed to total Negative Moment and total Positive moment All the Negative \& Positive moments are distributed in the column strips \& Middle strips respectively.

\subsection{Equivalent Frame Method:}

In this method moments at each joint is calculated by Moment Distribution Method using the Fixed End Moment on each span. Using those moments calculate negative moments at both left \& right support i.e. (Mu)$\&$ the maximum positive moments in the middle of span i.e. $(\mathrm{Mu}+)$. 


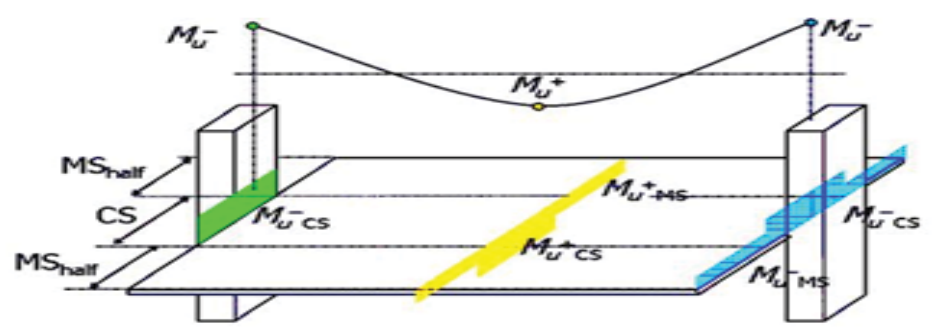

Fig.2.1 Distribution moment to the column strip and middle strip III. PROBLEM FORMULATION

Analysis of flat slab of size $5 \mathrm{~m} \mathrm{X} 5 \mathrm{~m}$ and $7 \mathrm{~m}$ X $7 \mathrm{~m}$ providing drop and column head. Size of columns is $500 \mathrm{~mm}$ X $500 \mathrm{~mm}$ and live load on the panel is $4 \mathrm{kN} / \mathrm{m} 2$. Take floor finishing load as $1 \mathrm{kN} / \mathrm{m} 2$. UseM20 concrete and Fe 415 steel. Slab is modelled using SAFE software. By using

1) Direct Design Method

2) Equivalent Frame Method

Table 3.1 Description of modelled 5m X 5m Slab

\begin{tabular}{|c|c|}
\hline Floor height & $3 \mathrm{~m}$ \\
\hline Size of columns & $500 \mathrm{~mm}$ X 500 mm \\
\hline Depth of slab & $170 \mathrm{~mm}$ \\
\hline Depth of drop & $220 \mathrm{~mm}$ \\
\hline Size of Drop & $2.5 \mathrm{~mm} \mathrm{X} 2.5 \mathrm{~mm}$ \\
\hline Grade of Concrete & M20 \\
\hline Grade of Steel & Fe 415 \\
\hline
\end{tabular}

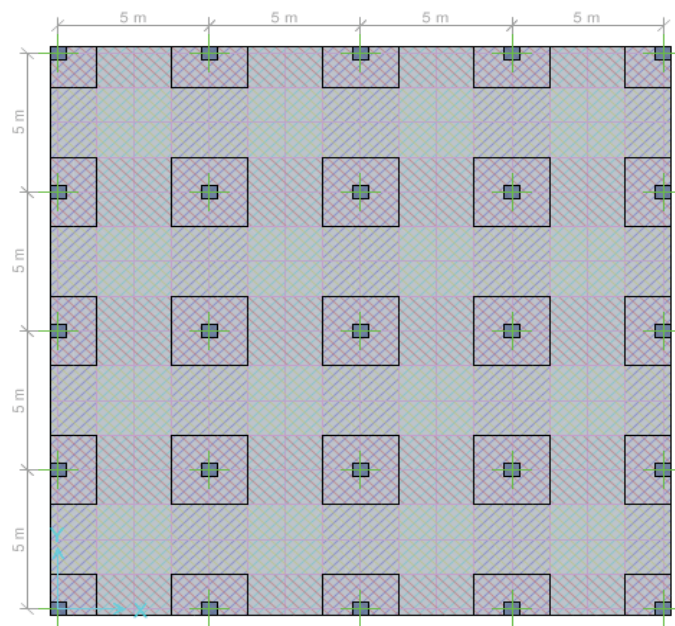

Fig.2.1Plan view of $5 \mathrm{~m} \times 5 \mathrm{~m}$ model Table 3.2 Description of modelled $7 \mathrm{~m} \mathrm{X} 7 \mathrm{~m}$ Slab

\begin{tabular}{|c|c|}
\hline Floor height & $3.5 \mathrm{~m}$ \\
\hline Size of columns & $500 \mathrm{~mm}$ X $500 \mathrm{~mm}$ \\
\hline Depth of slab & $230 \mathrm{~mm}$ \\
\hline Depth of drop & $290 \mathrm{~mm}$ \\
\hline Size of Drop & 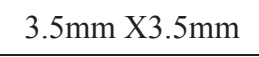 \\
\hline Grade of Concrete & M20 \\
\hline Grade of Steel & $\mathrm{Fe} 415$ \\
\hline
\end{tabular}




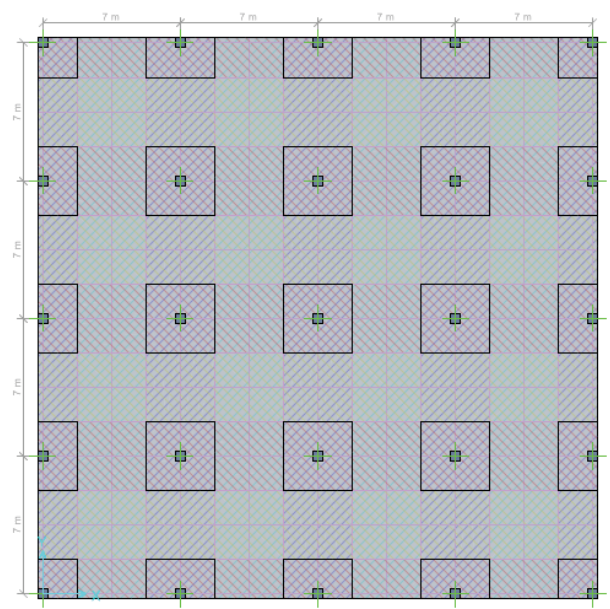

Fig 3.2Plan view of $7 \mathrm{~m} \times 7 \mathrm{~m}$ model

IV. RESULTS AND DISSCUSION

Table 4.1 Results of modelled 5m X 5m Slab For Exterior Panel

\begin{tabular}{|c|c|c|c|c|}
\hline \multirow{2}{*}{\begin{tabular}{c} 
Moments \\
\multirow{3}{*}{ Positive Moment (Span) }
\end{tabular}} & Strip & DDM & EFM & $\begin{array}{c}\text { FEM } \\
\text { Using SAFE }\end{array}$ \\
\hline & & & & 15.03 \\
\cline { 2 - 4 } Negative Moment (Interior Support) & M.S & 8.53 & 12.24 & 12.26 \\
\cline { 2 - 5 } & M.S & 27.6 & 21.65 & 18.20 \\
\hline \multirow{3}{*}{ Negative Moment (Exterior Support) } & C.S & 31.71 & 26.46 & 27.14 \\
\cline { 2 - 5 } & M.S & 0 & 0 & 0 \\
\hline
\end{tabular}

Table 4.2 Results of modelled 5m X 5m Slab For Interior Panel

\begin{tabular}{|c|c|c|c|c|}
\hline \multirow{2}{*}{\begin{tabular}{c} 
Moments \\
\multirow{3}{*}{ Positive Moment (Span) }
\end{tabular}} & Strip & DDM & EFM & $\begin{array}{c}\text { FEM } \\
\text { Using SAFE }\end{array}$ \\
\hline \multirow{2}{*}{ Negative Moment at Support } & C.S & 11.66 & 17.04 & 11.24 \\
\cline { 2 - 5 } & M.S & 7.8 & 11.36 & 8.09 \\
\hline & C.S & 27.1 & 20.38 & 37.4 \\
\hline
\end{tabular}




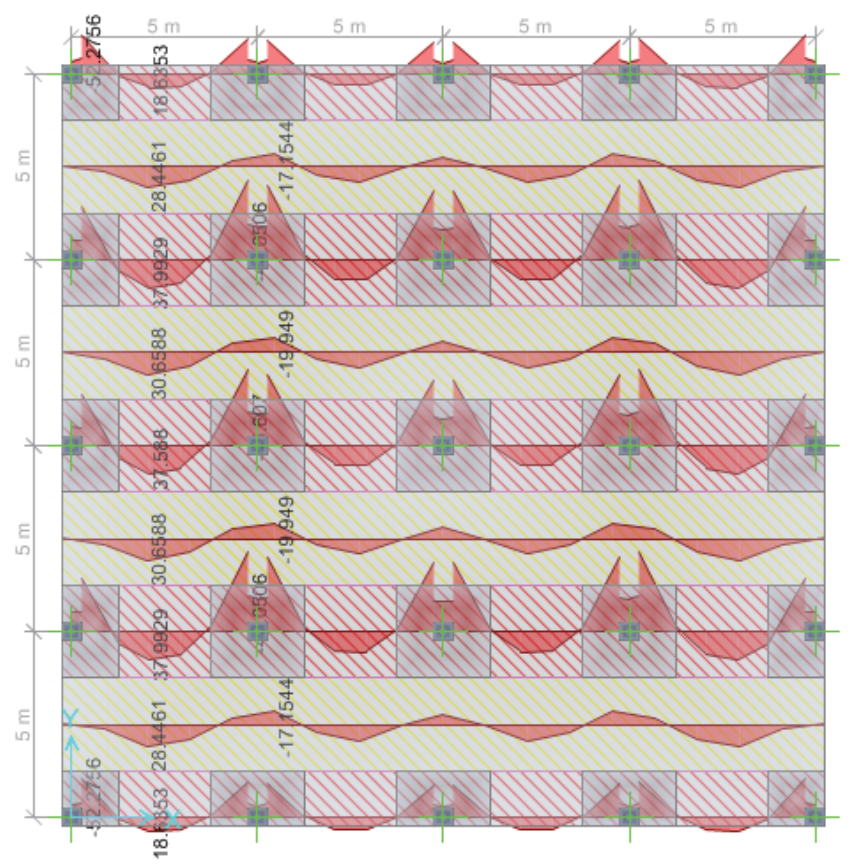

Fig 4.1BMD of $5 \mathrm{~m} \times 5 \mathrm{~m}$ model from SAFE

Table 4.3 Results of modelled 7m X 7m Slab For Exterior Panel

\begin{tabular}{|c|c|c|c|c|}
\hline \multirow{2}{*}{\begin{tabular}{c} 
Moments \\
\multirow{3}{*}{ Positive Moment (Span) }
\end{tabular}} & Strip & DDM & EFM & $\begin{array}{c}\text { FEM } \\
\text { Using SAFE }\end{array}$ \\
\hline \multirow{3}{*}{ Negative Moment (Interior Support) } & & & & 57.84 \\
\cline { 2 - 4 } & C.S & 31.07 & 45.6 & 44.08 \\
\hline \multirow{2}{*}{ Negative Moment (Exterior Support) } & M.S & 20.75 & 30.4 & 97.08 \\
\cline { 2 - 5 } & C.S & 61.9 & 50.78 & 31.29 \\
\hline
\end{tabular}

\begin{tabular}{|c|c|c|c|c|}
\hline Moments & Strip & DDM & EFM & $\begin{array}{c}\text { FEM } \\
\text { Using SAFE }\end{array}$ \\
\hline \multirow[b]{2}{*}{ Positive Moment (Span) } & C.S & 26.1 & 39.18 & 36.57 \\
\hline & M.S & 17.2 & 26.12 & 25.45 \\
\hline \multirow[b]{2}{*}{ Negative Moment at Support } & C.S & 59.9 & 46.71 & 91.42 \\
\hline & M.S & 19.75 & 15.57 & 31.29 \\
\hline
\end{tabular}

Table 4.4 Results of modelled 7m X 7m Slab For Interior Panel 


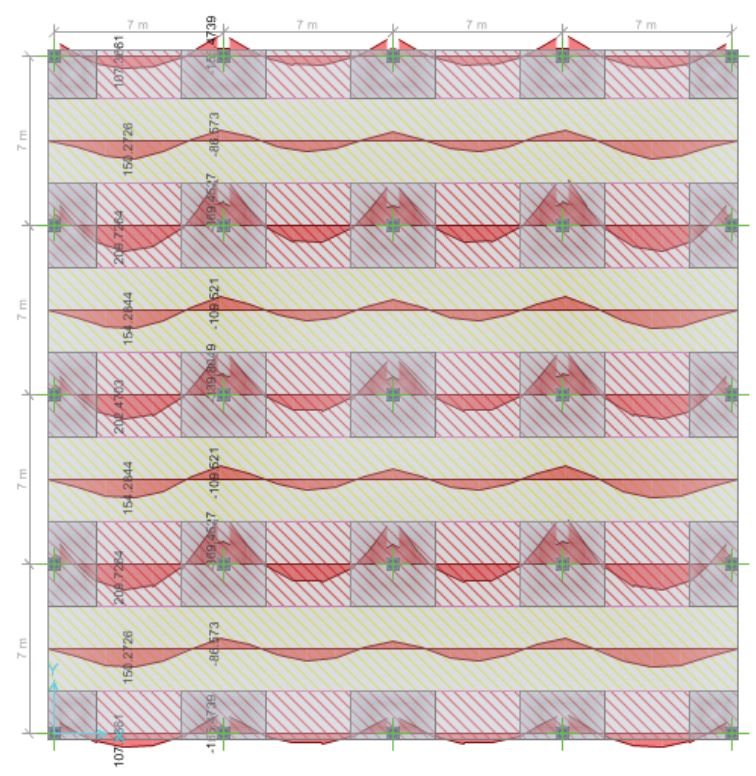

Fig 4.2BMD of $7 \mathrm{~m} \times 7 \mathrm{~m}$ model from SAFE

\section{COMPARISON}

As compare to DDM the positive mid-span moment is increasing and negative moment is decreasing when slab is analysed with Equivalent Frame Method. The positive mid-span moment is increasing and negative moment is decreasing when slab is analysed with Equivalent Frame Method. The negative moment section shall be designed to resist the larger of the two interior negative design moments for the span framing into common supports

\section{CONCLUSION}

Based on above results and discussions the following conclusions are drawn,

1. The design of flat slab by Direct Design Method has some restrictions that (a) It should have minimum three spans in each directions and (b) It should not have staggered column orientation. Hence Equivalent Frame Method is adopted.

2. Both Direct design method and Equivalent frame method are approximate methods but results obtained from Equivalent frame method are more accurate.

3. The equivalent frame method is not satisfactory for hand calculations. Therefore, use of computers software which based on Finite Element Analysis is adopted.

\section{REFERENCES}

[1] Patil\&Sigi "Flat Slab Construction in India,"International Journal of Engineering and Innovative Technology (IJEIT) Volume 3, Issue 10, April 2014

[2] Patil\&Sigi “Analysis And Design Of Flat Slabs Using Various Codes,'International Journal of Research in Engineering and Technology (IJRET) Volume 3, Issue 4, April 2014.

[3] Bahoria and Parbat "Analysis and Design of RCC and Post-tensioned Flat Slabs Considering Seismic Effect," IACSIT International Journal of Engineering and Technology, Vol. 5, No. 1, February 2013.

[4] Franklin S. O. (2010). "On yield line estimates of the punching strength of full panel unbonded post-tensioned flat slabs at internal columns", ARPN Journal of Engineering and Applied Sciences, Vol. 5, No. 12, 65-70.

[5] Patil\&Sigi "Flat Slab Construction in India,"International Journal of Engineering and Innovative Technology (IJEIT) Volume 3, Issue 10, April 2014

[6] Bharathi\&Chandrashekar "Review \& Design of Flat Plate/Slab Construction in India"

[7] Amit A, Shavane, R S Deotale "Analysis and Design of Flat Slab and Grid slab and their Cost Comparison" International Journal of Engineering Research and Applications, ISSN: 2248-9628, vol.1, Issue 3, pp.837-848.

[8] Patil\&Sigi “Analysis And Design Of Flat Slabs Using Various Codes,"International Journal of Research in Engineering and Technology (IJRET) Volume 3, Issue 4, April 2014. 
[9] Patil and Shinde "Comparative Study of Flat Plate Structure With RCC Beam Column Structure" International Journal of Engineering Research Volume 3,Issue 32015.

[10] "Fundamentals of Reinforced Concrete",(2005) by Sinha.

[11] P.C. Varghese "Advanced Reinforced Concrete Design”, New Delhi, EEE (2002).

[12] Bureau of Indian Standards, New Delhi, "IS 456:2000, Plain and Reinforced Concrete - Code of Practice", Fourth Revision, July (2000).

[13] Pimanmas A., Warnitchai P. and Pongpornsup S. (2004). "Seismic performance of 3/5 scaled post tensioned interior flat slab column connections", Asia conference on earthquake engineering, Manila.

[14] Prawatwong U., TandianC.H. andWarnitchai P. (2008). "Seismic performance of post-tensioned interiorslab-column connections with and without drop panel", The 14th World Conference on Earthquake Engineering, Beijing, China. 